\title{
PENGARUH GEL EKSTRAK DAUN SIRIH MERAH (Piper crocatum Ruiz \& Pav) TERHADAP PENYEMBUHAN LUKA BAKAR PADA KELINCI (Oryctolagus cuniculus).
}

\section{THE EFFECT OF RED BETEL LEAF EXTRACT GEL (Piper crocatum Ruiz \& Pav) FOR HEALING BURNS IN RABBITS (Oryctolagus cuniculus).}

\author{
Fina Ulviani ${ }^{{ }^{*}}$, Yusriadi ${ }^{1}$, Khildah Khaerati ${ }^{1}$ \\ ${ }^{1}$ Jurusan Farmasi, Fakultas MIPA,UniversitasTadulako, Palu, Indonesia
}

Received 12 Agustus 2016, Accepted 18 September 2016

\begin{abstract}
ABSTRAK
Telah dilakukan penelitian mengenai formulasi sediaan gel ekstrak daun sirih merah (Piper crocatum Ruiz \& Pav) untuk pengobatan luka bakar pada kelinci (Oryctolagus cuniculus).Penelitian ini bertujuan untuk mengetahui pengaruh variasi konsentrasi ekstrak daun sirih merah dalam gel terhadap pengobatan luka bakar pada kelinci yang diinduksikan logam panas. Pada penelitian ini ekstrak kental sirih merah diformulasi menjadi sediaan gel dengan konsentrasi 1\%, 2\% dan 3\%. Pengujian mutu fisik gel yang dilakukan meliputi uji organoleptik, pH,homogenitas dan daya sebar pada penyimpanan hari ke-0sampai hari ke-28. Uji aktivitas gel dilakukan pada 5 ekor kelinci yang dibagi dalam 5 kelompok perlakuan. Setiap kelinci dibuat luka bakar menggunakan lempeng logam panas berdiameter $20 \mathrm{~mm}$. Masing-masing kelompok diberi lima luka yang terdiri atas kontrol negatif, formula ekstrak 1\%, formula ekstrak $2 \%$, formula ekstrak $3 \%$ dan kontrol positif. Pengukuran diameter luka dilakukan pada hari ke-1, ke-3, ke-5, ke-7, ke-9 hingga hari ke-21.Data persentase penyembuhan luka bakar di analisis secara statistik dengan metode Two-Way ANOVA.Hasil penelitian menunjukkan bahwa variasi konsentrasi ekstrak memberikan pengaruh terhadap kecepatan penyembuhan luka. Gel dengan konsentrasi ekstrak daun sirih merah 3\% memiliki efek penyembuhan yang paling besar dengan persentase penyembuhan $85,81 \%$ dibandingkan dengan gel ekstrak $1 \%$ dan $2 \%$ dengan persentase $65,32 \%$ dan $76,58 \%$.
\end{abstract}

Kata kunci : Gel, Sirih Merah (Piper crocatum Ruiz \& Pav), Luka Bakar, Oryctolagus cuniculus.

\begin{abstract}
Research on Gel Formulation of red betel leaf extract (Piper crocatum Ruiz \& Pav) for the treatment of burn wounds in rabbits (Oryctolagus cuniculus) has been conducted. This study aimed to determine variation's effect of concentration in gel of red betel leaf extract for the treatment of burn wounds in rabbits which had been wounded using hot metal. In this study, the viscous extract was formulated into gel with concentrations of $1 \%, 2 \%$ and $3 \%$. The Gel's Physical quality evaluation included organoleptic, $\mathrm{pH}$, homogeneity and dispersive ability tests on day 0 until day 28. The gel activity test was performed on 5 rabbits divided into five treatment groups. Each rabbit was burn-wounded using hot metal plate at diameter of $20 \mathrm{~mm}$. Each group was given five wounds consisting of a negative control, 1\%, 2\%, 3\% of extract formula and a positive control. The diameter measurement of the wounds was done on the $1 \mathrm{st}, 3 \mathrm{rd}, 5 \mathrm{th}, 7 \mathrm{th}, 9 \mathrm{th}$ and the $21 \mathrm{st}$ day. Data of wound healing percentage was statistically analyzed with Two-Way ANOVA. The results showed that the gel with $3 \%$ of red betel leaf extract of which percentage of healing as much as $85.81 \%$ compared to gel extract $1 \%$ and $2 \%$ with percentage $65,32 \%$ dan $76,58 \%$.
\end{abstract}

Keywords: Gel, Red Betel (Piper crocatum Ruiz \& Pav), Burn wound, Oryctolagus cuniculus.

*Corresponding author : Fina Ulviani, finaulviani@yahoo.com (ph : +62-853-4246-7117) 


\section{PENDAHULUAN}

Salah satu cara penanganan pada penderita luka bakar yaitu mengobati luka dengan menggunakan sediaan topikal (Inriani, 2012). Pemberian sediaan topikal yang tepat dan efektif diharapkan dapat mengurangi dan mencegah infeksi pada luka (Rismana E, 2013).Bentuk sediaan topikal yang dapat dengan mudah digunakan untuk pengobatan pada luka bakar salah satunya adalah sediaan gel.Sediaan gel merupakan sediaan yang memiliki daya sebar yang baik diantara sediaan topikal lainnya sehingga lebih mudah untuk dioleskan pada luka.Selain itu sediaan gel memiliki komponen penyusun yang sebagian besarnya adalah air, sehingga memudahkan pelepasan zat aktif dari sediaan gel ke dalam luka sehingga dapat membantu mempercepat penyembuhan luka.

Tanaman sirih merah (Piper crocatum Ruiz \& Pav) merupakan salah satu tanaman obat yang daunnya telah lama dikenal mempunyai khasiat obat untuk menyembuhkan berbagai penyakit, secara turun temurun telah digunakan dan dapat menyembuhkan berbagai jenis penyakit, salah satunya yaitu digunakan untuk mengobati luka.Daun sirih merah mengandung senyawa aktif seperti minyak atsiri, alkaloid, saponin, tanin, dan flavonoid (Indri W, 2008).Dengan adanya saponin memacu pembentukan kolagen yang berperan dalam proses penyembuhan luka (Abdassah, 2009). Selain itu kandungan minyak atsiri yang terdapat dalam sirih merah mempunyai aktivitas antibakteri yang dapat membantu mencegah terjadinya infeksi pada luka bakar dan kandungan flavonoidnya juga efektif sebagai antiinflamasi. Hal ini didukung dengan penelitian yang telah dilakukan bahwa minyak atsiri daun sirih merah memiliki KHM terhadap bakteri gram positif Bacillus cereus, Staphylococcus aureus dan Staphylococcus epidermidis secara berurutan $1 \%, 0,25 \%$ dan $0,5 \%$ (Soerya Dewi, 2013). Serta penelitian ekstrak daun sirih merah memberikan aktivitas antiinflamasi paling baik dengan dosis 50 $\mathrm{mg} / \mathrm{kgBB}$ yang mampu menurunkan radang sebesar $85,61 \%$ (Atik, 2011). Karena adanya senyawa kimia yang dapat berkhasiat sebagai antiinflamasi dan antibakteri maka ada kemungkinan daun sirih merah juga dapat berkhasiat sebagai obat untuk luka bakar.
Berdasarkan hal tersebut peneliti tertarik untuk melakukan formulasi gel ekstrak daun sirih merah dengan variasi konsentrasi ekstrak daun sirih merah untuk pengobatan luka bakar pada kelinci yang diinduksi logam panas.

\section{BAHAN DAN METODE Bahan}

Bahan-bahan yang digunakan dalam penelitian ini yaitu daun sirih merah (Piper crocatum Ruiz dan Pav), aluminium foil, akuades, etanol 96\% (teknis), triethanolamin (teknis), metil paraben, carbopol, gliserin, gel Bioplacenton dan ketamin.

\section{Metode \\ Pengambilan sampel}

Daun sirih merah diambil di KelurahanPengawu, Kecamatan Palu Barat, Sulawesi Tengah. Daun yang diambil adalah daun segar, tidak cacat dan dipetik secara manual (tangan) dan disortasi basah untuk ekstraksi.

\section{Ekstraksi Daun Sirih Merah}

Pembuatan ekstrak etanol daun sirih merah dilakukan dengan cara ekstraksi dengan metode maserasi dengan menggunakan etanol 96\%. Daun sirih merah yang sudah kering diblender hingga halus. Kemudian dimasukkan serbuk ke dalam wadah maserasi dan ditambahkan etanol 96\% hingga serbuk terendam. Diaduk dan didiamkan selama $3 \mathrm{x}$ 24 jam lalu disaring untuk mendapatkan filtrat. Lalu filtrat yang diperoleh dipekatkan dengan rotary evaporator hingga didapatkan ekstrak kental dan ditimbang untuk menghitung rendemennya.

\section{Formulasi gel ekstrak daun sirih merah}

Formulasi gel ekstrak daun sirih merah dapat dilihat pada tabel dibawah ini :

Tabel 1. Formula Gel

\begin{tabular}{llcccc}
\hline No & Nama bahan & \multicolumn{4}{c}{$\begin{array}{c}\text { Formulasi dan komposisi } \\
\text { (\%b/v) }\end{array}$} \\
\cline { 3 - 6 } & & F1 & F2 & F3 & F4 \\
\hline 1. & Ekstrak daun & - & 1 & 2 & 3 \\
sirih merah & & & & \\
2. & Carbopol & 2 & 2 & 2 & 2 \\
3. & $\begin{array}{l}\text { Triethanola } \\
\text { min }\end{array}$ & 2 & 2 & 2 & 2 \\
4. & Gliserin & 10 & 10 & 10 & 10 \\
\hline
\end{tabular}




\begin{tabular}{llllll}
\hline 5. & $\begin{array}{l}\text { Metil } \\
\text { paraben }\end{array}$ & 0,2 & 0,2 & 0,2 & 0,2 \\
$6 . \quad$ Air ad & 100 & 100 & 100 & 100 \\
\hline
\end{tabular}

\section{Cara Pembuatan Gel Ekstrak Daun Sirih Merah}

Sediaan gel yang dibuat sebanyak 100 gram. Carbopol dikembangkan dalam akuades hingga mengembang kemudian diaduk menggunakan stirer sambil ditambahkan triethanolamin sedikit demi sedikit hingga terbentuk massa gel. Selanjutnya ditambahkan gliserin dan Sejumlah ekstrak yang telah dilarutkan ditambahkan kedalam massa gel sambil terus diaduk. Metil paraben yang telah dilarutkan dalam air panas, ditambahkan kedalam massa gel dan terus diaduk sampai homogen, lalu dimasukkan kedalam wadah.

\section{Pengujian Stabilitas Fisik Krim}

1. Pengamatan Organoleptik sediaan

Evaluasi organoleptis secara visual mulai dari tekstur, warna dan bau dari gel.

2. Pengujian homogenitas sediaan

Gel dioleskan pada kaca transparan dimana sediaan diambil 3 bagian yaitu atas, tengah dan bawah. Homogenitas ditunjukkan dengan tidak adanya butiran kasar.

3. Pengukuran $\mathrm{pH}$ sediaan gel

$\mathrm{pH}$ sediaan gel diukur dengan menggunakan alat pengukuran $\mathrm{pH}$ yang dilakukan dengan cara mencelupkan katoda $\mathrm{pH}$ meter ke dalam sediaan gel, $\mathrm{pH}$ sediaan akan tertera pada monitor.

4. Pengukuran Daya Sebar

Ditimbang gel ekstrak daun sirih merah sebanyak $0,5 \mathrm{~g}$, kemudian diletakkan dengan hati-hati di atas lempeng kaca berukuran $20 \times 20 \mathrm{~cm}$. Selanjutnya ditutupi dengan lempeng kaca yang lain dan digunakan pemberat diatasnya hingga bobot mencapai $125 \mathrm{~g}$ dan diukur diameternya setelah 1 menit.

\section{Pemilihan hewan uji}

Dalam pengujian ini hewan coba yang digunakan adalah kelinci (Oryctolagus cuniculus)yang sehat,dengan berat badan 1,0$1,9 \mathrm{~kg}$.Hewan coba dibagi secara acak ke dalam 5 kelompok perlakuan.

\section{Pengujian efek gel ekstrak daun sirih merah terhadap luka bakar}

Sebelum dilakukan proses penginduksian luka bakar, bulu di sekitar punggung dicukur, kemudian kelinci dianastesi dengan injeksi ketamin yang disuntikan di pembuluh darah pada telinga. Luka bakar dibuat menggunakan solder listrik yang terhubung logam yang berdiameter 20 $\mathrm{mm}$ dengan suhu $65^{\circ} \mathrm{C}$. Solder dipanaskan selama 5 menit kemudian ditempelkan pada kulit punggung kelinci selama 7 detik sampai terbentuk luka bakar. Kemudian, pada kulit yang melepuh atau mengalami luka bakar tersebut dioleskan $200 \mathrm{mg}$ sediaan gel secara merata pada permukaan luka dengan interval pengolesan 1 kali sehari selama 21 hari.Pengamatan dilakukan secara visual dengan memperhatikan perubahan diameter luka.Pengukuran diameter luka dilakukan dengan menggunakan jangka sorong.

\section{Analisis Data}

Data yang dianalisis yaitu persentase penyembuhan luka bakar yang diperoleh melalui pengukuran rata-rata diameter luka bakar.Pengukuran dilakukan pada hari 1, 3, 5, 7, 9, 11, 13, 15, 17, 19 dan 21.Data hasil pengujian efek sediaan gel ekstrak daun sirih merah terhadap perubahan diameter luka bakar kemudian dianalisis dengan menggunakan metode Two-way Anova peningkatan penyembuhan luka bakar pada setiap dan untuk melihat apakah ada perbedaan yang signifikan di setiap perlakuan.Selanjutnya untuk mutu fisik sediaan seperti pHdan daya sebar dianalisis menggunakan ujit-student.

\section{HASIL DAN PEMBAHASAN Hasil}

Hasil rendemen yang diperoleh dari proses ekstraksisebesar $6,14 \%$. Hasil rata-rata penyembuhan luka bakar dari dasar gel, gel ekstrak daun sirih merah $1 \%$, gel ekstrak daun sirih merah $2 \%$, gel ekstrak daun sirih merah 3\% dan Bioplacenton dapat dilihat pada Tabel 2 , sedangkan untuk hasil mutu fisik sediaan yang meliputi, organoleptik, homogenitas, $\mathrm{pH}$ dan daya sebar dapat dilihat pada Tabel 3, 4, 5, dan 6 berikut ini. 
Tabel 2. Pengukuran rata-rata persentase penutupan luka selama penyimpanan

\begin{tabular}{lccc}
\hline $\begin{array}{l}\text { Kelompok } \\
\text { perlakuan }\end{array}$ & & & \\
& & & \\
\cline { 2 - 4 } & 3 & 5 & 7 \\
\hline FI (K-) & 6,1 & 10, & 14, \\
& 4 & 47 & 49 \\
F2 (E 1\%) & 6,3 & 14, & 15, \\
& 5 & 16 & 52 \\
F3 (E2\%) & 8,2 & 10, & 20, \\
& 1 & 47 & 76 \\
F4 (E 3\%) & 10, & 17, & 21 \\
& 97 & 62 & \\
F5 (K+) & 11, & 20 & 26, \\
& 60 & & 97
\end{tabular}

Tabel 3. Pengamatan organoleptik selama penyimpanan

\begin{tabular}{|c|c|c|c|c|c|}
\hline \multirow[t]{2}{*}{ Pengamatan } & \multirow[t]{2}{*}{ Sediaan } & \multicolumn{4}{|c|}{ Pengamatan hari ke- } \\
\hline & & 0 & 7 & 14 & 21 \\
\hline \multirow{5}{*}{ Tekstur } & F1(K-) & $\mathrm{AK}$ & $\mathrm{AK}$ & $\mathrm{AK}$ & $\mathrm{AK}$ \\
\hline & $\mathrm{F} 2(\mathrm{E} 1 \%)$ & $\mathrm{K}$ & $\mathrm{K}$ & K & K \\
\hline & F3 (E 2\%) & $\mathrm{K}$ & $\mathrm{K}$ & $\mathrm{K}$ & $\mathrm{K}$ \\
\hline & F4 (E 3\%) & $\mathrm{K}$ & $\mathrm{K}$ & K & K \\
\hline & $\mathrm{F} 1(\mathrm{~K}-)$ & B & B & B & B \\
\hline \multirow{4}{*}{ Warna } & F2 (E 1\%) & $\mathrm{H}$ & $\mathrm{H}$ & $\mathrm{H}$ & $\mathrm{H}$ \\
\hline & F3 (E2\%) & $\mathrm{HP}$ & $\mathrm{HP}$ & HP & $\mathrm{HP}$ \\
\hline & F4 (E 3\%) & $\mathrm{HK}$ & $\mathrm{HK}$ & HK & HK \\
\hline & F1 (K-) & $\mathrm{E}$ & $\mathrm{E}$ & $\mathrm{E}$ & $\mathrm{E}$ \\
\hline \multirow{3}{*}{ Bau } & $\mathrm{F} 2(\mathrm{E} 1 \%)$ & BK & $\mathrm{BK}$ & BK & BK \\
\hline & F3 (E 2\%) & $\mathrm{BK}$ & $\mathrm{BK}$ & BK & $\mathrm{BK}$ \\
\hline & F4 (E 3\%) & $\mathrm{BK}$ & $\mathrm{BK}$ & $\mathrm{BK}$ & $\mathrm{BK}$ \\
\hline $\begin{array}{r}\text { Keterangan: K } \\
\mathrm{AK} \\
\mathrm{B} \\
\mathrm{E} \\
\mathrm{H} \\
\mathrm{H} \\
\mathrm{H} \\
\mathrm{B}\end{array}$ & $\begin{array}{l}\text { kental } \\
\text { gak kental } \\
\text { bau khas eks } \\
\text { bau khas basi } \\
\text { warna hijau } \\
\text { warna hijau } \\
\text { warna hijau } \\
\text { bening }\end{array}$ & aman & mera & & \\
\hline \multicolumn{6}{|c|}{ Tabel 4. Data Homogenitas } \\
\hline No. & \multicolumn{2}{|c|}{ Formula } & \multicolumn{3}{|c|}{ Hasil } \\
\hline 1 & \multicolumn{2}{|c|}{ F1 (K-) } & \multicolumn{3}{|c|}{$\mathrm{H}$} \\
\hline 2 & \multicolumn{2}{|c|}{$\mathrm{F} 2(\mathrm{E} 1 \%)$} & \multicolumn{3}{|c|}{$\mathrm{H}$} \\
\hline 3 & \multicolumn{2}{|c|}{$\mathrm{F} 3(\mathrm{E} 2 \%)$} & \multicolumn{3}{|c|}{$\mathrm{H}$} \\
\hline 4 & \multicolumn{2}{|c|}{$\mathrm{F} 4(\mathrm{E} 3 \%)$} & \multicolumn{3}{|c|}{$\mathrm{H}$} \\
\hline
\end{tabular}

Tabel 5 Rata-rata pengukuran $\mathrm{pH}$ sediaan selama peyimpanan

\begin{tabular}{lccccc}
\hline \multirow{2}{*}{ Sediaan } & \multicolumn{5}{c}{ pH hari ke- } \\
\cline { 2 - 6 } & 0 & 7 & 14 & 21 & 28 \\
\hline F1 (K-) & 6,58 & $5,35^{*}$ & $5,67^{*}$ & $5,63^{*}$ & $5,5^{*}$ \\
F2 (E 1\%) & 6,75 & $5,39^{*}$ & $5.6^{*}$ & $5,4^{*}$ & $5,29^{*}$ \\
F3 (E 2\%) & 6,82 & $5,35^{*}$ & $5,42^{*}$ & $5,28^{*}$ & $5,13^{*}$ \\
F4 (E 3\%) & 6,83 & $5,58^{*}$ & $5,48^{*}$ & $5,32^{*}$ & $5,46^{*}$ \\
\hline Keterangan: * menunjukkan & perbedaan & yang & signifikan \\
dibandingkan hari ke-0 & & & &
\end{tabular}

Tabel 6. Rata-rata pengukuran daya sebar sediaan selama penyimpanan

Sediaan Daya sebar hari ke-

$(\mathrm{cm})$

\begin{tabular}{lccccc} 
& 0 & 7 & 14 & 21 & 28 \\
\hline F1 (K-) & 3,71 & $3,62^{*}$ & $3,49 *$ & $3,45^{*}$ & $3,42^{*}$ \\
F2 (E 1\%) & 3,72 & $3,56 *$ & $3,46 *$ & $3,41 *$ & $3,41 *$ \\
F3 (E 2\%) & 3,78 & $3,56 *$ & $3,53 *$ & $3,45 *$ & $3,39 *$ \\
F4 (E 3\%) & 3,92 & $3,79 *$ & $3,65 *$ & $3,59 *$ & $3,45^{*}$ \\
\hline Keterangan: * & menunjukkan & perbedaan & yang & signifikan \\
dibandingkan hari ke-0 & & & &
\end{tabular}

Pembahasan

Penelitian ini menggunakan ekstrak daun sirih merah Piper crocatum Ruiz \& Pav). Tanaman yang dijadikan ekstrak telah di identifikasi di UPT Sumber Daya Hayati Sulawesi, Universitas Tadulako untuk memastikan bahwa tanaman yang digunakan merupakan benar sirih merah (Piper crocatum Ruiz \& Pav) famili Piperaceae. Pembuatan simplisia kering dengan cara daun sirih merah (Piper crocatum Ruiz \& Pav) yang telah dipetik dikeringkan dengan cara dianginanginkan pada suhu kamar, dirajang dan KK diblender hingga diperoleh serbuk simplisia BK kering. Serbuk simplisia tersebut kemudian diekstraksi dengan metode maserasi menggunakan pelarut etanol $96 \%$ selama 3 hari dan disaring untuk memisahkan ekstrak dengan filtrat.Ekstrak cair tersebut dikentalkan dengan menggunakan rotary evaporator. Pemilihan metode maserasi karena merupakan cara ekstraksi yang paling sederhana dan tidak memerlukan banyak biaya, cairan penyari akan menembus dinding sel dan masuk ke dalam rongga sel yang mengandung zat aktif, zat aktif akan larut karena adanya perbedaan konsentrasi antara larutan zat aktif di dalam sel dan di luar sel maka larutan yang terpekat didesak ke luar. Cairan penyari yang digunakan adalah etanol $96 \%$ yang mana efektif dalam menghasilkan jumlah bahan aktif yang optimal (Voight, 1994) juga mudah berpenetrasi ke dalam sel serta bersifat universal yang mampu menarik semua jenis zat aktif, baik bersifat polar, semi polar dan non polar juga kadar toksisitasnya rendah (Ditjen POM, 1986).

Sediaan yang dibuat dalam penelitian ini yaitu sediaan gel. Gel dipilih karena memiliki kandungan air yang tinggi dan memiliki daya sebar yang baik dibandingkan dengan sediaan topikal lainnya. Carbopol digunakan sebagai bahan pembentuk gel atau 
gelling agent karena dapat membentuk gel pada konsentrasi rendah yaitu $0,5 \%$. Carbopol menghasilkan basis yang bening transparan dengan tekstur lebih baik dibandingkan dengan $\mathrm{NaCMC}$ dan natrium alginate (Djajadisastra, 2009). Trietanolamin ditambahkan sebagai bahan penetral untuk karbopol yang bersifat asam, triethanolamin akan meningkatkan viskositas dari sediaan gel. Selanjutnya gliserin digunakan sebagai humektan yang akan mempertahankan kandungan air dalam sediaan sehingga sifat fisik dan stabilitas sediaan selama penyimpanan dapat dipertahankan (Allen, 2002). Dalam formula ini digunakan metil paraben sebagai bahan pengawet karena bersifat sebagai antimikroba yang efektif pada kisaran $\mathrm{pH}$ yang luas dan memiliki aktivitas antimikroba yang kuat (Rowe, 2002).Air digunakan sebagai medium pendispersinya.

Sebelum dilakukan pembuatan sediaan gel dengan variasi konsentrasi ekstrak daun sirih merah, terlebih dahulu dilakukan orientasi basis gel carbopol untuk menentukan konsentrasi carbopol yang baik bila akan dicampurkan dengan ekstrak daun sirih merah. Hasil orientasi basis gel pada menunjukkan bahwa formula 3 memiliki tekstur yang agak kental dibandingkan dengan formula 1 dan 2 , dimana pada formula 1 dan 2 memiliki tekstur yang encer.

Pemeriksaan organoleptis dilakukan secara visual pada suhu kamar dengan mengamati sediaan gel berdasarkan bentuk, warna dan bau dapat dilihat pada (Tabel 3) hasil pengamatan organoleptis sediaan gel ekstrak daun sirih merah menunjukkan bahwa pada F2 (gel ekstrak 1\%) berwarna hijau, F3 (gel ekstrak 2\%) hijau pekat, dan F4 (gel ekstrak 3\%) hijau kehitaman. Selama penyimpanan semua gel yang mengandung ekstrak tetap memiliki bau khas ekstrak daun sirih merah. Sedangkan F1 (gel tanpa ekstrak daun sirih merah) memiliki jernih, transparan dan bau khas dari basis. Tekstur disetiap formula berbeda-beda, pada F1 memiliki konsistensi yang agak kental, hal ini disebabkan karena pada F1 hanya terdiri dari basis gel, sementara pada formula yang mengandung ekstrak 1\%,2\% dan 3\% memiliki konsistensi yang kental, hal ini dikarenakan karena adanya penambahan ekstrak daun sirih merah yang mengakibatkan gel semakin kental. Sehingga pada saat dimasukkan ke dalam basis gel mengakibatkan konsistensinya
berubah.Hal ini dapat diketahui bahwa semakin tinggi konsentrasi ekstrak daun sirih merah dalam formula maka akan semakin menambah konsistensi dari gel tersebut.

Uji pH dilakukan pada setiap formula sediaan gel.Berdasarkan hasil analisis menggunakan metode $t$-student, terlihat perbedaan yang signifikan pada setiap formula (Tabel 5).Untuk F1 terjadi perbedaan yang signifikan dari hari ke-0 sampai hari ke-28. Untuk F2, F3 dan F4 dari hari ke-0 sampai dengan hari ke-28 juga terjadi perbedaan yang signifikan. Perbedaan ini menunjukkan bahwa pH dari sediaan tidak stabil selama penyimpanan, ketidakstabilan ini dapat disebabkan suhu ruangan dan penyimpanan yang kurang baik (Young et, 2002). Namun, kisaran $\mathrm{pH}$ yang dihasilkan oleh sediaan masih berada dikisaran $\mathrm{pH}$ kulit yaitu 4,5-6,5 sehingga sediaan gel ekstrak daun sirih merah aman untuk digunakan, karena $\mathrm{pH}$ yang terlalu asam dapat mengiritasi kulit dan $\mathrm{pH}$ yang terlalu basa dapat membuat kulit bersisik (Olivia, 2013).

Pengujian homogenitas sediaan dilakukan dengan cara mengoleskan sejumlah tertentu sediaan pada sebuah kaca objek kemudian dilihat berdasarkan ada atau tidaknya gumpalan maupun butiran kasar pada sediaan gel. Berdasarkan hasil pengujian menunjukkan bahwa semua sediaan gel baik basis gel, gel dengan ekstrak daun sirih merah $1 \%, 2 \%$ dan 3\% homogeny (Tabel 4).

Pengujian daya sebar untuk setiap sediaan dilakukan untuk melihat kemampuan menyebar pada kulit, hasil pengujian $t$-student daya sebar menunjukkan bahwa setiap formula terdapat perbedaan yang signifikan (Tabel 6), dimana FI, F2, F3 dan F4 selama penyimpanan dari hari ke-0 sampai dengan hari ke-28 terjadi perbedaan yang signifikan. Hal ini menunjukkan bahwa daya sebar dari setiap formula tidak stabil selama penyimpanan. Daya sebar yang dihasilkan dari sediaan tidak memenuhi kriteria daya sebar yang baik untuk sediaan gel yaitu antara 5-7 cm (Martin, 1990) dimana daya sebar yang dihasilkan yaitu antara 3-4 cm, hal ini disebabkan karena konsistensi dari sediaan yang terlalu kental sehingga daya sebarnya menjadi lebih kecil.Perbedaan daya sebar sangat berpengaruh pada kecepatan difusi zat aktif dalam melewati membran.Semakin tinggi daya sebar suatu sediaan maka luas permukaannya semakin besar, mengakibatkan kecepatan 
difusi suatu obatpun semakin meningkat (Hasyim, 2012).

Uji aktivitas sediaan dilakukan terhadap hewan uji kelinci (Oryctolagus cuniculus).Sebelum induksi luka bakar, bulu di sekitar punggung dicukur dan kelinci dianastesi dengan injeksi ketamin.Jalur pemberian obat anastesi ketamin diberikan melalui intravena pada telinga kelinci.Ketamin dipilih sebagai obat anastesi karena jalur pemberiannya melalui intravena yang mempunyai mula kerja yang cepat dan masa kerja yang singkat, serta digunakan untuk pembedahan jangka singkat (Kee, 1996).

Induksi luka bakar pada kulit punggung kelinci menggunakan solder listrik yang telah dimodifikasi. Pada kulit yang melepuh atau mengalami luka bakar dilakukan pengamatan secara visual dari kulit kelinci, yang mana terdapat kerusakan pada jaringan epidermis dan sedikit dermis dengan ciri-ciri: kulit mengalami pelepuhan, kulit kering, dan dasar luka berwarna merah pucat (Moenadjat, 2003). Dari hasil pengamatan tersebut dapat dikatakan bahwa hewan uji mengalami luka bakar derajat II dangkal dengan diameter ratarata luka bakar yaitu 20,61 mm. Sediaan gel dioleskan $200 \mathrm{mg}$ secara merata pada permukaan luka dengan interval pengolesan 1 kali sehari selama 21 hari. Pengamatan luka bakar yang diberikan pada kelinci menunjukkan perubahan yang sangat berarti, dimana luka tertutupi dahulu pada bagian atasnya oleh darah yang membeku yang membentuk lapisan kerak atau scab.

Proses penyembuhan luka bakar terdiri dari 3 fase untuk menggantikan jaringan yang rusak. Proses pertama yaitu fase inflamasi, fase ini berlangsung sejak terjadinya luka sampai hari kelima, dimana pembuluh darah yang terputus pada luka yang menyebabkan pendarahan dan tubuh akan berusaha menghentikannya dengan cara vasokontriksi, pengerutan ujung pembuluh darah yang terputus. Selanjutnya fase proliferasi, fase ini berlangsung sampai minggu ketiga.dimana pada fase proliferasi luka dipenuhi dengan sel radang, fibroplasia dan kolagen, membentuk jaringan berwarna kemerahan dengan permukaan yang berbenjol halus yang disebut granulasi (Rismana, 2010). Fase akhir dari proses penyembuhan luka yaitu fase penyudahan, dimana terjadi penyerapan kembali jaringan yang berlebih dan perupaan kembali jaringan yang terbentuk, fase ini dapat berlangsung selama berbulan-bulan dan berakhir tanda radang sudah hilang (Syamsuhidayat, 1997).

Hasil pengujian TwowayAnova terhadap persentase penyembuhan luka bakar menunjukkan hasil penyembuhan yang berbeda signifikan dari setiap formula. Dengan bertambahnya waktu akan terjadi peningkatan terhadap penyembuhan luka. Persentase penyebuhan luka bakar dari setiap formula yaitu F1 (kontrol negatif) sebesar 55,14\%, F2 (gel ekstrak 1\%) 66,71\%, F3 (gel ekstrak 2\%) $76,75 \%$, F4 (gel ekstrak 3\%) 85,81\% dan F5 (Kontrol positif) 92,91\%. Dari semua formula gel ekstrak daun sirih merah memiliki efek terhadap penyembuhan luka bakar, semakin tinggi konsentrasi ekstrak daun sirih merah maka semakin besar persentase penyembuhan luka bakarnya, tetapi untuk penyembuhannya, kontrol positif Bioplacenton memiliki persentase penyembuhan luka yang lebih besar dibandingkan dengan formula yang mengandung ekstrak daun sirih merah.

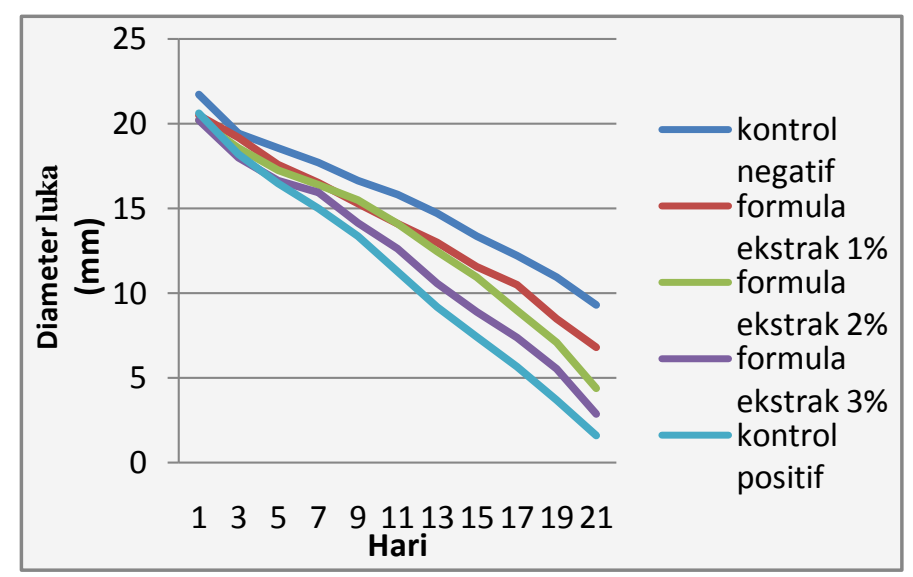

Gambar 1. Grafik hubungan antara diameter luka vs hari

Adanya aktivitas antiinflamasi dan antibakteri dari daun sirih merah diduga karena adanya aktivitas senyawa-senyawa metabolit sekunder yang terdapat dalam sirih merah yaitu minyak atsiri, saponin, tanin dan flavonoid.Hal ini dibuktikan melalui penapisan fitokimia yang dilakukan yang menunjukkan bahwa ekstrak daun sirih merah positif mengandung senyawa flavonoid, alkaloid, tanin dan polifenol.Aktivitas antiinflamasi ekstrak daun sirih merah diduga karena adanya senyawa golongan flavonoid saponin dan tanin. Mekanisme flavonoid dalam menghambat proses terjadinya inflamasi melalui dua cara, yaitu dengan menghambat 
permeabilitas kapiler dan menghambat metabolisme asam arakidonat sehingga produksi prostaglandin berkurang. Flavonoid juga menghambat sekresi enzim lisosom yang merupakan mediator inflamasi. Penghambatan mediator inflamasi ini dapat menghambat proliferasi dari proses radang (Robinson, 1995). Sedangkan mekanisme antiinflamasi saponin adalah dengan menghambat kenaikan permeabilitas vaskular (Atik, 2011).

Selain flavonoid, tanin juga mempunyai aktivitas antiinflamasi.Tanin mempunyai aktivitas antioksidan. Antioksidan berperan sebagai antiinflamasi dengan berbagai cara yaitu (1) menghambat produksi oksidan $\left(\mathrm{O}_{2}\right)$ oleh neutrofil, monosit dan makrofag. Penghambatan produksi oksidan $\mathrm{O}_{2}$ akan mengurangi pembentukan $\mathrm{H}_{2} \mathrm{O}_{2}$ yang mengakibatkan produksi asam hipoklorid (HOCl) dan $\mathrm{OH}$ ikut terhambat. (2) menghambat langsung oksidan reaktif seperti radikal hidroksi $(\mathrm{OH})$ dan asam hipoklorid (Robinson, 1995). Senyawa-senyawa aktif yang terkandung dalam daun sirih merah inilah yang diduga mampu untuk membantu dalam proses penyembuhan luka bakar.

Hasil penelitian menunjukkan bahwa variasi konsentrasi ekstrak memberikan pengaruh terhadap kecepatan penyembuhan luka. Gel dengan konsentrasi ekstrak daun sirih merah 3\% memiliki efek penyembuhan yang paling besar dengan persentase penyembuhan $85,81 \%$ dibandingkan dengan gel ekstrak 1\%dan 2\% dengan persentase $65,32 \%$ dan 76,58\%. Berdasarkan hasil tersebut perlu dilakukan uji tentang isolasi golongan senyawa dalam sirih merah yang memiliki efektifitas sebagai antiinflamasi, juga perlu dilakukan formulasi sediaan topikal lainnya dengan penambahan konsentrasi ekstrak, karena semakin besar konsentrasi ekstrak daun sirih merah makan akan semakin besar penyembuhan luka bakar.

\section{DAFTAR PUSTAKA}

Abdassah, M., Sumiwi, S.A., Hendrayana, J. (2009). Formulasi Ekstrak Daun Sukun (Artocarpus Altilis (Parkins.) Fosberg) Dengan Basis Gel Sebagai Antiinflamasi. Jurnal Farmasi Indonesia, 4 (4), 199 -209.
Allen. (2002). The Art, Science, and Technology of Pharmaceutical Compounding. $2^{\text {nd }} E d$. American Pharmaceutical Association Washington,D.C.

Atik. (2011). Uji Antiinflamasi Ekstrak Metanol Daun Sirih Merah (Piper crocatum Ruiz \& Pav), Fakultas Farmasi, Universitas Jember, 8.

Ditjen POM. (1986), Sediaan Galenik, Departemen Kesehatan Republik Indonesia, Jakarta, 12, 26.

Djajadisastra., J., Munim, A., \& Dessy, N.P. (2009). Formulasi Gel Topikal dari Ekstrak Nerii Folium dalam Sediaan Anti Jerawat, Jurnal Farmasi Indonesia, 4(4).

Hasyim, N., Pare K. L., Junaid I., Kurniati, A. (2012). Formulasi Dan Uji Efektivitas Gel Luka Bakar Ekstrak Daun Cocor Bebek (Kalanchoe pinnata L.) Pada Kelinci (Oryctolagus cuniculus). Majalah Farmasi dan Farmakologi, 16(2), 89-94.

Indri, W.W., Anthoni, M.S.S.,\& Setyorini, W. (2008). Sirih Merah, Balai Kajian Teknologi Pertanian Yogyakarta: Yogyakarta. Hal 1-4.

Inriani, M. M. R., dkk. (2012). Formulasi dan uji krim ekstrak umbi singkong (Manihot esculenta) terhadap luka bakar pada kelinci (Oryctolagus cuniculus), FMIPA-UNSRAT, Manado.

Kee, J,L. (1995). Buku Saku Pemeriksaan Laboratorium dan Diagnostik Dengan Implikasi Keperawatan., Penerbit Buku Kedokteran EGC., Jakarta.

Martin, A.J., Swarbrick, \& Cammarata, A. (1993). Farmasi Fisik: Dasar-dasar Farmasi Fisik dalam Ilmu Farmasetik. Edisi Ketiga, Penerjemah: Yoshita, UIPress: Jakarta, 1176-1182.

Olivia, H. (2013), Pengaruh Basis Salep Terhadap Formulasi Sediaan Salep Ekstrak Daun Kemangi (Ocinum sanctum L) Pada Kulit Punggung 
Kelinci Yang Dibuat Infeksi

Staphylococcus aureus, FMIPA-

UNSRAT, Manado.

Rismana, E. (2010). Pengembangan Formulasi Sediaan Topikal Wound Healing Menggunakan Bahan Aktif Kitosan dan Ekstrak Pegagan, Pusat Teknologi Farmasi Dan Medika Deputi Bidang TAB - BPPT, Jakarta.Hal 7.

Robinson, T. (1995), Kandugan Organik Tumbuhan Tingkat Tinggi, Penerbit ITB, Bandung.

Rowe, (2009). Handbook Of Pharmaceutical Excipients, Sixth Edition. Pharmaceutical Press And American Pharmacists Association, Washington. 139, 312, 470, 783.
Soerya Dewi. (2013). Aktivitas Antibakteri Minyak Atsiri Daun Sirih Merah (Piper crocatum ruiz \& pav.), Jurusan Kimia, Fakultas Matematika dan Ilmu Pengetahuan Alam, Universtas SebelasMaret, Kentingan Surakarta. 7.

Syamsuhidayat, R.\& Jong, W.D. (1997). Buku Ajar Ilmu Bedah: Luka Bakar. Erlangga: Jakarta.

Voight, R. (1994). Buku Pelajaran Teknologi Farmasi Edisi $V$, diterjemahkan oleh DR. Soedani Neorono, Gadjah Mada University Press, Yogyakarta. 336-337.

Young, A. (2002), Practical Cosmetic Science, Mills and Boon Limited, London, 3940 